\title{
The COVID-19 global inflection point and Europe's predicament
}

\section{Nathalie Tocci $^{1}$}

Published online: 18 May 2020

(C) Springer-Verlag GmbH Germany, part of Springer Nature 2020

COVID-19 will likely represent an inflection point in the international system by accentuating and accelerating global dynamics that had been building up for some time. At the epicentre of the cyclone, Europeans have been looking in so far. The jury is still out on whether internal European efforts will succeed in making or breaking a true Union. However, as time goes by, lifting our gaze internationally will become just as existential.

That the world had exited its unipolar moment, in which the hegemony of the USA dominated world affairs, we have known for a long time. This system started fraying as multiple centres of power, first amongst which China, emerged and a growing rivalry between Washington and Beijing took root. This rivalry had already spilled into conflict in the trade and digital domains. With COVID-19, it has acquired clear ideological undertones too.

China, originally the bête noir of the coronavirus, has since been leveraging its two comparative advantages. As the first country having successfully curtailed the virusfor the time being - it has set a lockdown model that could influence political trends in Europe and beyond. True, European countries have avoided the massive physical control and manipulation of public information we have seen in China, as well as the extensive collection of citizen data to limit contagion that could eventually be used for other purposes. However, mutatis mutandis, we have mainly followed the Chinese lockdown model. We all face a growing dilemma between public health and privacy, in which fear of the pandemic tilts us towards security and away from rights. And some European countries, beginning with Hungary, have gone much further, putting a formal end to their democracy altogether.

Beyond providing a model, China has leveraged its role as the global manufacturing hub, exporting masks, ventilators, and other medical equipment worldwide. True, the recognition of this power will likely spur a revision of globalization towards shorter

Dr. Nathalie Tocci is director of the Istituto Affari Internazionali in Rome, special advisor to HRVP Josep Borrell, and Honorary professor at the University of Tübingen.

Nathalie Tocci

n.tocci@iai.it

1 Rome, Italy 
global supply chains and greater redundancies. True too, China's show of solidarity in Europe has now been eclipsed by the fact that Member States are being shaken out of their inexcusable lethargy and gut national instincts. Today, EU border policy is coordinated, medical equipment flows within the internal market, and even intensive care places are being made available to those countries most in need. Moreover, Europeans are beginning to do for themselves what China cannot: help each other navigate the dire socio-economic consequences of this epochal crisis. From the casting aside of the Stability Pact and the European Central Bank's temporary asset purchase, to a European unemployment scheme and an eventual move towards Eurobonds, the EU is beginning to rise internally to the challenge.

Internally, Europeans may thus succeed in standing united. Internationally, however, one thing is clear: we may be sceptical about China's global leadership, but the USA too is nowhere to be seen. Washington's disdain for a "foreign" virus, its unilateral travel ban on its supposedly closest allies in Europe, its inhuman tightening sanctions on coronavirus-infected Iran, its blocking of G7 unity, and its embarrassing attempts to secure exclusive American rights to a German-produced vaccine all point to an unprecedented absence of US global leadership. In past decades, America was applauded by some and despised by others, but no one challenged its influence on world affairs. Today, it is not a question of agreeing or disagreeing with the USA, but rather of not seeing it on the global map at all. Beijing may well fail to seize Washington's mantle of global leadership, but the latter has clearly lost it for the time being.

A post-COVID-19 leaderless world could trigger a further weakening of the rulesbased multilateral system, already debilitated by nationalism, protectionism, and a move towards a US-China decoupling. This crisis could fuel demands for economic autarky, driving scepticism for interdependence, cooperation, and openness. And as trade protectionism becomes engrained and the incentives to protect the shared gains from global economic integration dwindle, the twentieth century global economic governance system could quickly atrophy.

This is why turning outwards will become just as important for Europeans than building internally a true and more resilient Union. Amidst a sharpening the US-China strategic competition, Europeans must redouble their quest for autonomy, enabling them to triangulate between the two rather than being forced to choose between or to succumb to one of them. Such autonomy is necessary to shield Europeans against the nefarious effects of asymmetric interdependence aimed at making the continent simply another terrain of the crystallizing global confrontation.

But its purpose is not just defensive. The COVID-19 crisis highlights more than ever the need for European leadership in sustaining and upgrading the multilateral rulesbased system - an existential interest for the Union. Globally, COVID-19 has laid bare the limits of a governance architecture that merely monitors and suggests, rather than enforces. Nowhere is this clearer than in the World Health Organization. This crisis suggests that what Europe and the world need is more international cooperation, rules, norms, and institutions, not less. As the staunchest supporter of the United Nations, the onus is on Europe to make the post-COVID-19 world one inaugurated by a renewed UN moment. Work must be done to ensure a transparent exchange of information and best practices in confronting a crisis such as COVID-19 using standardized methodologies for the collection of data. Likewise, cooperation in the supply of medical 
equipment is the minimum requirement for an effective international response. No less important is the need to mobilize multilateral forums like the G20 to alleviate the global economic impact of a crisis which, unlike 2007-2008, has begun in the real economic but could spill into financial markets too. On top, COP26 represents the opportunity to ensure that an eventual restart of global growth is a green one. With two European countries - the UK and Italy - chairing COP26 and the 2021 G20, elevating these two global governance platforms is an opportunity that Europeans cannot miss.

Just as important will be European leadership in revamping, rather than side-lining, the sustainable development agenda, notably in fragile and conflict areas in our surrounding regions. Ethiopia's Prime Minister, Abiy Ahmed, has warned about the dire consequences if the coronavirus is not defeated in Africa, not only because of the devastating human and economic impact on the world's most vulnerable regions but also because of the risk of a rebound of the pandemic to Europe and the rest of the world. The onus is on Europeans not only to mobilize immediately existing resources to bolster the fragile health sectors in these countries but also to ensure that the guiding principle of the 2021-2027 Multi Annual Financial Framework is as much internal as international solidarity. On top, COVID-19 should galvanize a final push towards a more coherent European international financial architecture, in which both the EIB and the EBRD as well as member state agencies would coordinate to jointly mobilize funds.

As Europeans struggle with the drizzly daily count of their dead and infected, the social anxiety of their lockdown, and the economic catastrophe it is bringing about, lifting our gaze is not intuitive. But much like Europeans now see how there is no way of defeating this virus by standing alone, we must also recognize that we are globally on the same boat as Pope Francis put it. It is Europe's responsibility to act upon its words and make multilateralism great again. 